\title{
Characterization of Monoclonal Antibodies against
}

\section{Human Apolipoprotein E}

\author{
R. W. Milne, Ph. Douste-Blazy, and Y. L. MARCEL, Laboratory of Lipoprotein \\ Metabolism, Clinical Research Institute of Montreal, Montreal H2W 1R7, \\ Quebec, Canada \\ L. RETEGUI, Unité de Médecine Expérimentale, International Institute of \\ Cellular Pathology, Brussels, Belgium
}

A B S T RACT From a single cell fusion, five stable hybridomas secreting antiapolipoprotein $\mathrm{E}$ (apo E) were obtained. The immunoglobulin (Ig)G subclasses containing the respective monoclonal antibodies were isolated and were used as the antibody component in a solid-phase radioimmunoassay. The binding of ${ }^{125} \mathrm{I}$ apo $\mathrm{E}$ to the insolubilized antibody was inhibited by unlabeled apo $\mathrm{E}$ but not by unlabeled apoproteins A-I, A-II, C-II, and C-III, or by low density lipoprotein immunodepleted of endogenous apo E. Competition curves were obtained with lipoprotein subfractions that had the same shape as those obtained with purified apo E. Apo E levels in normal and hyperlipidemic plasma were well correlated when measured by the five monoclonal antibodies and polyclonal anti-apo $\mathrm{E}$, although differences in absolute values were observed. In normal subjects $34,10,20$, and $36 \%$ of apo $E$ was recovered in the very low density lipoprotein, low density lipoprotein, high density lipoprotein, and the $d>1.21 \mathrm{~g} / \mathrm{ml}$ fractions, respectively, whereas these values were $34,7,12$, and $47 \%$, respectively, in type III patients. All antibodies indicated the same subfraction distribution of apo $\mathrm{E}$. The monoclonal antibodies reacted with all of the isomorphs of apo $E$. One of the antibodies could be clearly distinguished by its reactivity with chemically modified very low density lipoprotein.

\section{INTRODUCTION}

Apolipoprotein E (apo E) ${ }^{1}$ is the most actively synthetized apolipoprotein in the rat and appears to be of

Dr. Retegui is Fellow of the Consejo Nacional de Investigaciones Cientificas y Técnicas de la Republica Argentina.

Received for publication 3 November 1980 and in revised form 3 March 1981.

${ }^{1}$ Abbreviations used in this paper: apo E, B, etc., apolipoprotein E, B, etc.; FBS, fetal bovine serum; HBSS, Hanks' balanced salt solution; HDL, high density lipoprotein; LDL, low density lipoprotein; RIA, radioimmunoassay; VLDL, very low density lipoprotein. exclusively hepatic origin (1-3). In humans as in swine, apo $B$ and apo $E$ are respectively responsible for the binding of low density lipoprotein (LDL) and of a minor high density lipoprotein (HDL) subclass to a high-affinity cell-surface receptor on fibroblasts and other cell types $(4,5)$. The apo $E$ and apo $B$ are recognized by the same receptor and, in both cases, binding is abolished if the lysine or arginine residues of the apoproteins are chemically modified (6). It has been suggested that structurally similar positively charged regions on the two apoproteins serve as the recognition site for the receptor (7). In addition, apo $\mathrm{E}$ appears to be responsible for the hepatic uptake of a subfraction of homologous (8) and heterologous (9) HDL from rat plasma.

Monoclonal antibodies to apoproteins provide a new approach to the study of the specificity of the interaction of lipoproteins and cell surface receptors. The advantage of monoclonal antibodies lies in their specificity for a single antigenic determinant. It is possible that with a battery of monoclonal antibodies to an apoprotein one could immunochemically define regions of the apoprotein involved in binding to the cell surface receptor.

We report the production and partial characterization of five monoclonal antibodies against human apo $\mathbf{E}$.

\section{METHODS}

Preparation of plasma and plasma lipoproteins. Blood from fasted normal subjects or from fasted type IIA, type III, or type IV hyperlipidemic patients of the lipid clinic of the Clinical Research Institute of Montreal was collected into EDTA.

Lipoprotein subfractions were prepared in a Beckman L5-65 ultracentrifuge with a 50.2 $\mathrm{Ti}$ rotor (Beckman Instruments, Inc., Spinco Div., Palo Alto, Calif.). The very low density lipoprotein (VLDL), LDL, and HDL were isolated at densities of $1.006,1.006-1.063$, and $1.063-1.21 \mathrm{~g} / \mathrm{ml}$, respectively. The infranate, $d>1.21 \mathrm{~g} / \mathrm{ml}$, was also retained for analysis. 
Purification of apo E. The VLDL from normal fasted subjects was isolated as described above and delipidated with ethanol/diethylether $(3: 2)$ at a ratio of $25 \mathrm{vol}$ of solvent/vol of VLDL. The VLDL precipitate was then subjected to two further extractions in diethylether. The moist apolipoprotein was redissolved in a buffer consisting of $2 \mathrm{mM}$ phosphate, $5 \mathrm{M}$ urea, and $10 \mathrm{mM}$ dithiothreitol ( $\mathrm{pH}$ 7.4). The sample was applied to a column of heparin (Upjohn Co., Kalamazoo, Mich.) bound to Sepharose 4B (10), which had been preequilibrated with $2 \mathrm{mM} \mathrm{NaHPO}$ and $5 \mathrm{M}$ urea (pH 7.4). After extensive washing with the same buffer, the bound protein was eluted with $2 \mathrm{mM}$ Na phosphate buffer ( $\mathrm{pH} 7.4$ ), $5 \mathrm{M}$ urea, and $1 \mathrm{M} \mathrm{NaCl}$. The retained fraction was dialyzed against $2 \mathrm{mM}$ Na phosphate buffer ( $\mathrm{pH} 7.4$ ), made up to $5 \mathrm{M}$ urea, and reapplied to the heparin-Sepharose column, which was conditioned as above. The bound protein was eluted with a linear gradient $50-300 \mathrm{mM} \mathrm{NaCl}$ in $2 \mathrm{mM} \mathrm{Na}$ phosphate buffer (pH 7.4) and $5 \mathrm{M}$ urea. Apo $\mathrm{E}$ was eluted between 200 and $230 \mathrm{mM} \mathrm{NaCl}$ and its purity checked by alkaline polyacrylamide gel electrophoresis, by sodium dodecyl sulfate-polyacrylamide gel electrophoresis, and by isoelectric focusing on polyacrylamide gel (11). The isolated apo $E$ did not cross-react with antisera against other apoproteins.

The major polymorphic species of apo $E$ were isolated by preparative isoelectrofocusing (pI) of apo VLDL, as described previously (11). The VLDL was prepared from a plasma pool from normal donors. Thus obtained, apo $E_{1}, E_{2}$, $E_{3}, E_{4}$ had apparent pI of 5.60, 5.65, 5.72, and 5.80, respectively; their purity was assessed by analytical isoelectric focusing and by sodium dodecyl sulfate-polyacrylamide gel electrophoresis.

Cell lines. The azaquanine-resistant plasmacytoma cell line SP2-0 (12) obtained from Dr. Rolf Kemmler (Institut Pasteur, Paris) was recloned and maintained in an atmosphere of $8 \% \mathrm{CO}_{2}$ in Dulbecco's Modified Eagle's medium supplemented with $10 \%$ fetal bovine serum (FBS), $15 \mathrm{mM}$ Hepes, $50 \mu \mathrm{m}$ 2-mercaptoethanol, penicillin-streptomycin, and $1.5 \mu \mathrm{g} / \mathrm{ml}$ azaquanine.

Immunization of mice. $\mathrm{BALB} / \mathrm{c}$ mice, whose spleens were to be used for cell fusion were given a primary subcutaneous injection of $50 \mu \mathrm{g}$ of apo $\mathrm{E}$ in complete Freund's adjuvant. After $3 \mathrm{wk}$, the mice were given a second subcutaneous injection of $50 \mu \mathrm{g}$ apo $\mathrm{E}$ in complete Freund's adjuvant. 1 wk later and $3 \mathrm{~d}$ before the cell fusion, $2 \mu \mathrm{g}$ of apo $\mathrm{E}$ was injected intravenously.

BALB/c mice were also immunized intraperitonally, according to the protocol of Tung et al. (13), to induce ascites containing anti-apo $\mathrm{E}$ antibody.

Cell fusion. The technique used for cell fusion was similar to that described by Kennet et al. (14). A cell suspension in Hanks' balanced salt solution (HBSS) was prepared by teasing apart the spleens of two appropriately immunized mice. The cells were filtered through nylon cloth and centrifuged, and the erythrocytes lysed by osmotic shock. The cells were again centrifuged, filtered through nylon cloth, and washed in HBSS. The SP2-0 cells were washed twice in HBSS, mixed with the spleen cells at a ratio of $1: 10$, and again washed in HBSS. The pellet was resuspended in $0.2 \mathrm{ml}$ of $30 \%$ polyethylene glycol 1000 (J. T. Baker Chemical Co., Phillipsburg, N. J.), gently swirled for 2 min, and centrifuged for $6 \mathrm{~min}$ at $200 \mathrm{~g} .5 \mathrm{ml}$ of HBSS was added and the cells gently swirled for $3 \mathrm{~min}$ followed by centrifugation. $5 \mathrm{ml}$ of Dulbecco's modified Eagle's medium containing $15 \mathrm{mM}$ Hepes, $40 \mu \mathrm{M}$ 2-mercaptoethanol, 30\% FBS and penicillinstreptomycin was added. The pellet was left undisturbed for 5 min before gentle resuspension of the cells. The cells were diluted to $20 \mathrm{ml}$ with medium and distributed in two petri plates. After $24 \mathrm{~h}$ the cells were centrifuged and resuspended in the same medium, which in addition contained $0.11 \mathrm{mM}$ hypoxanthine, $0.38 \mu \mathrm{M}$ aminopterine, and $16 \mu \mathrm{M}$ thymidine (HAT) (15). The cells were then distributed in the wells of 11, 96-well microculture plates (Falcon Labware, Div. of Becton, Dickinson \& Co., Oxnard, Calif.). On 3 successive d, $50 \mu$ l of HAT-containing medium was added to each well. When sufficient growth had occurred, normally at 10-15 d, the supernate were screened for the presence of anti-apo $E$ antibody.

Screening of supernates. Aliquots of $200 \mu \mathrm{l}$ of a solution of apo $\mathrm{E}(10 \mu \mathrm{g} / \mathrm{ml}$ in $5 \mathrm{mM}$ glycine, $\mathrm{pH} 9.2)$ were distributed in Removawells (Dynatech Laboratories, Inc., Dynatech Corp., Alexandria, Va.) and left overnight. The following day the wells were washed in $0.15 \mathrm{M} \mathrm{NaCl}$ containing $0.25 \%$ Tween 20. An aliquot of hybridoma supernate diluted to 200 $\mu l$ in phosphate-buffered saline containing $5 \%$ FBS was added to each well and incubated for $3 \mathrm{~h}$ at $37^{\circ} \mathrm{C}$. The wells were washed in $0.15 \mathrm{M} \mathrm{NaCl} / 0.025 \%$ Tween and $200 \mu \mathrm{l}$ of purified ${ }^{125}$ I-anti-mouse Fab, diluted in phosphate-buffered saline containing 5\% FBS was added and incubated for a further $3 \mathrm{~h}$. The wells were washed and the bound radioactivity determined. To identify the immunoglobulin class and subclass of the antibody produced by positive clones, a similar radioimmunoassay was performed but with purified ${ }^{125} \mathrm{I}$-labeled antibody specific to an individual mouse immunoglobulin class or subclass substituted for the ${ }^{125} \mathrm{I}$-anti-Fab. The preparation of the anti-mouse immunoglobulin reagents has been described previously (16).

Maintenance of hybridomas in culture and as ascitic tumors. Once positive clones were identified, the cells were transferred to larger culture vessels and maintained in HATcontaining medium. The concentration of FBS was gradually reduced from 30 to $10 \%$.

Lightly irradiated (200-500 R) BALB/c mice were injected intraperitoneally with $5 \times 10^{6}$ cultured hybridoma cells. When sufficient ascitic fluid had accumulated, the mice were killed and the ascites collected. The ascitic cells were used to passage the tumor and the fluid was used as a source of monoclonal anti-apo $\mathbf{E}$ antibody.

Isolation of anti-apo E immunoglobulin. The IgG subclass containing the anti-apo $\mathrm{E}$ antibody was isolated from the ascitic fluid of hybridoma-bearing mice by elution from protein-A Sepharose 4B (Pharmacia Inc., Uppsala, Sweden) with a stepwise $\mathrm{pH}$ gradient (17).

Iodination. $\quad 5 \mu \mathrm{g}$ apo $\mathrm{E}$ was labeled with $1 \mathrm{mCi}$ of ${ }^{125} \mathrm{I}$ by the technique of Bolton and Hunter (18). The prelabeled Bolton-Hunter reagent was purchased from Amersham Corp. (Arlington Heights, Ill.). The iodinated protein was isolated by gel filtration on Sephadex G-25. Greater than $90 \%$ of the radioactivity was precipitated by trichloroacetic acid and 75 to $80 \%$ was bound by mouse antihuman apo $\mathrm{E}$. The specific activity was $\sim 7 \mu \mathrm{Ci} / \mu \mathrm{g}$.

Labeled apo $\mathrm{E}$ was stored at $4^{\circ} \mathrm{C}$ in phosphate-buffered saline containing 5\% FBS and used within $14 \mathrm{~d}$. If kept longer there was a decrease in immunoprecipitable apo $\mathrm{E}$.

Immunoglobulins were labeled by chloramine $T$ (19) and the free ${ }^{125}$ I was removed by passage on an anion-exchange resin AGl $\times 8$ (Bio-Rad Laboratories, Richmond, Calif.).

Radioimmunoassay. The monoclonal antibody IgG fraction (see above) was diluted in $5 \mathrm{mM}$ glycine ( $\mathrm{pH} \mathrm{9.2),} \mathrm{and} \mathrm{200-}$ $\mu l$ aliquots were distributed in Removawells and left overnight at room temperature. The dilution of antibody was chosen on the basis of preliminary experiments and the concentration ranged from 5 to $10 \mu \mathrm{g} / \mathrm{ml}$ protein depending on the individual clone. The wells were washed in $0.15 \mathrm{M}$ $\mathrm{NaCl} / 0.025 \%$ Tween. The sample to be tested was appropriately diluted in phosphate-buffered saline containing 
$5 \%$ FBS and mixed with ${ }^{125} \mathrm{I}$-apo E; the final concentration of ${ }^{125} \mathrm{I}$-apo $\mathrm{E}$ being $\sim 5 \mathrm{ng} / \mathrm{ml}$. An aliquot of the mixture $(200 \mu \mathrm{l})$ was transferred to the precoated wells and incubated overnight at room temperature. The wells were washed and the bound radioactivity determined. Under the conditions of the test and in the absence of unlabeled apo $\mathrm{E} \sim 30 \%$ of the added radioactivity was bound. Nonspecific binding (with normal mouse IgG fixed to the plastic) accounted for $<10 \%$ of the maximum specific binding. Results are expressed as $B / B_{0}$ where $B={ }^{125} I$-apo $E$ counts per minute bound- ${ }^{125} I$-apo $E$ nonspecifically bound, and $B_{0}={ }^{125} I$-apo $E$ bound in the absence of unlabeled apo E- ${ }^{125} \mathrm{I}$-apo $\mathrm{E}$ nonspecifically bound.

Chemical modification of VLDL. Protein modification reactions were adapted from methods described by Mahley et al. (7) and Weisgraber et al. (6). Carbamylation: to $0.5 \mathrm{mg}$ VLDL protein in $300 \mu$ l of $0.2 \mathrm{M}$ borate buffer. $(\mathrm{pH} 8.8$ ) was added 20 mg potassium cyanate. The sample was incubated for $20 \mathrm{~h}$ at $37^{\circ} \mathrm{C}$ and the reaction terminated by the addition of 100 $\mu \mathrm{l}$ of FBS.

Reductive methylation: to $0.5 \mathrm{mg}$ VLDL in $300 \mu \mathrm{l}$ of $0.2 \mathrm{M}$ sodium borate ( $\mathrm{pH} 8.8$ ) was added $25 \mu \mathrm{l}$ of a $40-\mathrm{mg} / \mathrm{ml}$ solution of sodium borohybride. The reaction was started by the addition of $1 \mu \mathrm{l}$ of aqueous formaldehyde (37\%) and additional $1-\mu \mathrm{l}$ aliquots were added at 5 -min intervals. At $30 \mathrm{~min}$ the reaction was either terminated by the addition of $100 \mu \mathrm{l} \mathrm{FBS}$ or a further aliquot of sodium borohybride solution was added and the sequence of formaldehyde additions repeated before termination of the reaction at $60 \mathrm{~min}$ with $100 \mu \mathrm{l}$ of FBS.

Cyclohexanedione treatment: to $0.5 \mathrm{mg}$ VLDL in $100 \mu \mathrm{l}$ $0.15 \mathrm{M} \mathrm{NaCl}$. was added $200 \mu \mathrm{l} 0.15 \mathrm{M}$ cyclohexanedione dissolved in $0.2 \mathrm{M}$ borate ( $\mathrm{pH} 8.1$ ). The samples were incubated at $37^{\circ} \mathrm{C}$ for periods from 15 to $120 \mathrm{~min}$. The reaction was terminated by the addition of $100 \mu \mathrm{l}$ FBS. The extent of modification was not determined.

\section{RESULTS}

Cell fusion and monoclonal antibodies. Growth was observed in 130 wells ( $12 \%$ ), which were randomly distributed over the 11 microculture plates. Eight clones were identified by radioimmunoassay that secreted anti-apo E antibody. Two of the clones failed to grow when transferred to larger culture vessels and could not be saved. Four of the surviving clones produced antibody of the $\operatorname{IgG}_{1}$ class (1D7, 3B7, 5D9, $6 \mathrm{C5}$ ), and two produced $\operatorname{IgG}_{2 \mathrm{~b}}$ antibody (6H7, 7C9). One clone, 5D9, has subsequently stopped secreting antibody.

Cells of each of the positive clones were injected intraperitoneally into syngenetic lightly irradiated mice and the resulting ascites collected. The IgG subclass that contained the respective monoclonal antibody was isolated by Staphylococcus protein A-Sepharose, as described in Methods. The agarose gel isoelectrofocusing patterns of the isolated immunoglobulin fractions are shown in Fig. 1.

Radioimmunoassay of apo E. Each of the monoclonal antibodies and mouse anti-apo $E$ have been used as the antibody component in a solid-phase radioimmunoassay (RIA). Purified human apo E, apo AI, apo AII, apo CII, apo CIII as well as LDL im-

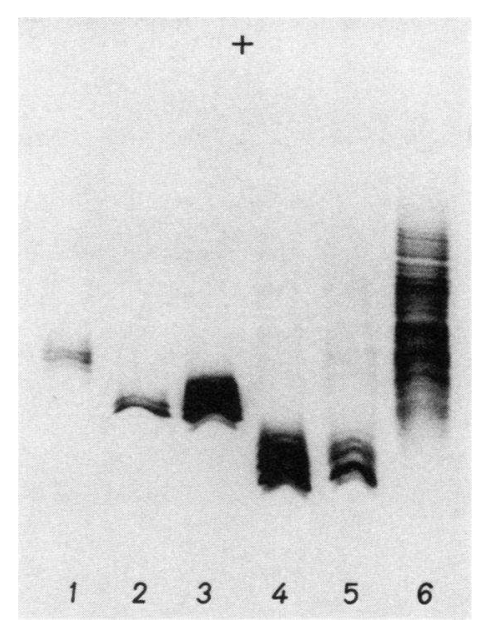

FIGURE 1 Isoelectrofocusing in agarose of 1D7 (1), 3B7 (2), $6 \mathrm{C} 5$ (3), 6H7 (4), 7C9 (5), and polyclonal mouse antihuman apo $\mathrm{E}(6)$. The IgG subclasses that contained the monoclonal antibody had been isolated from the ascitic fluid of hybridomabearing mice by elution from protein-A Sepharose. In the case of the polyclonal anti-apo E, the total IgG fraction was isolated on protein-A sepharose from the ascitic fluid of mice immunized with apo $E$.

munodepleted of endogenous apo $\mathrm{E}$ were tested for their ability to compete with ${ }^{125}$ I-apo E. Typical competition curves are shown in Fig. 2. The lower limit of detection of purified apo $\mathrm{E}$ was in the range of 5 to $15 \mathrm{ng}$ protein, dependent upon the individual antibody. Complete inhibition occurred with $>100-500$ ng apo E, again dependent upon the antibody. At high concentration, apo AII, apo CII, and apo CIII competed with ${ }^{125} \mathrm{I}$-apo $\mathrm{E}$, which would indicate a probable minor contamination $(<1 \%)$ of these apoprotein preparations with apo E. Porcine and African green monkey plasma, even at low dilutions, competed poorly with ${ }^{125}$ I-human apo $\mathrm{E}$ for the monoclonal and polyclonal antihuman apo $\mathrm{E}$ antibody (not shown).

When dilutions of human plasma or lipoprotein subfractions were tested in the RIA, the competition curves were parallel to that of purified apo E (Fig. 3). Although delipidation, heating the sample at $45^{\circ} \mathrm{C}$ for $30 \mathrm{~min}$, or treatment with $8 \mathrm{M}$ urea caused a decrease in measurable apo $\mathrm{E}$ in plasma, the shape of the curve was unchanged (not shown).

The apo $\mathrm{E}$ concentration in the plasma of six normal, 10 type II, 10 type IV, and 2 type III subjects was determined by RIA using four monoclonal and one polyclonal mouse antihuman apo E IgG. The mean and standard deviations are given in Table I. The correlation coefficients between determinations made by different antibodies ranged from 0.93 to 0.99 . In addition, lipoprotein subfractions of the normal and type III plasmas were prepared and the apo $\mathrm{E}$ concentrations determined. RIA using different monoclonal antibodies indicated an essentially identical dis- 


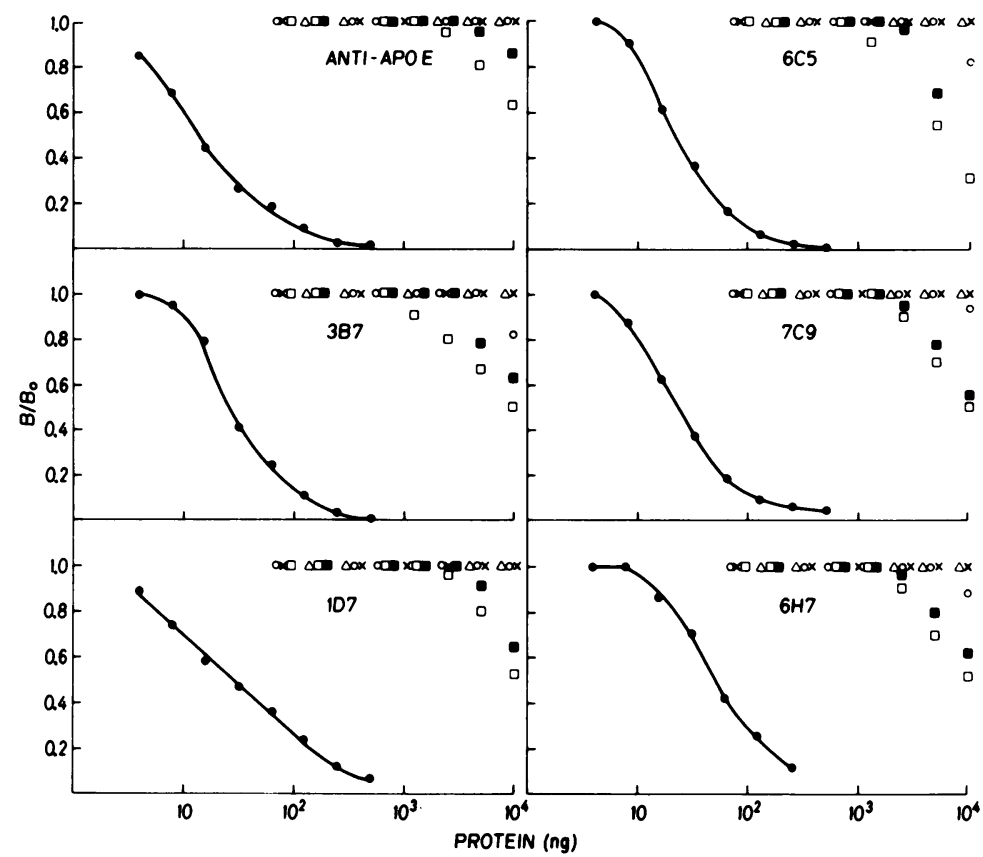

Figure 2 Dilutions of purified apo E (๑), apo AI (x), apo AII (O), apo CII ( $\square$ ), apo CIII ( $\square$ ), and LDL previously passed over insolubilized mouse antihuman apo $E(\Delta)$ were tested in a RIA for their ability to compete with ${ }^{125} \mathrm{I}$-apo $\mathrm{E}$. The five monoclonal anti-apo $\mathrm{E}$ antibodies or polyclonal anti-apo E IgG were used as the antibody component.

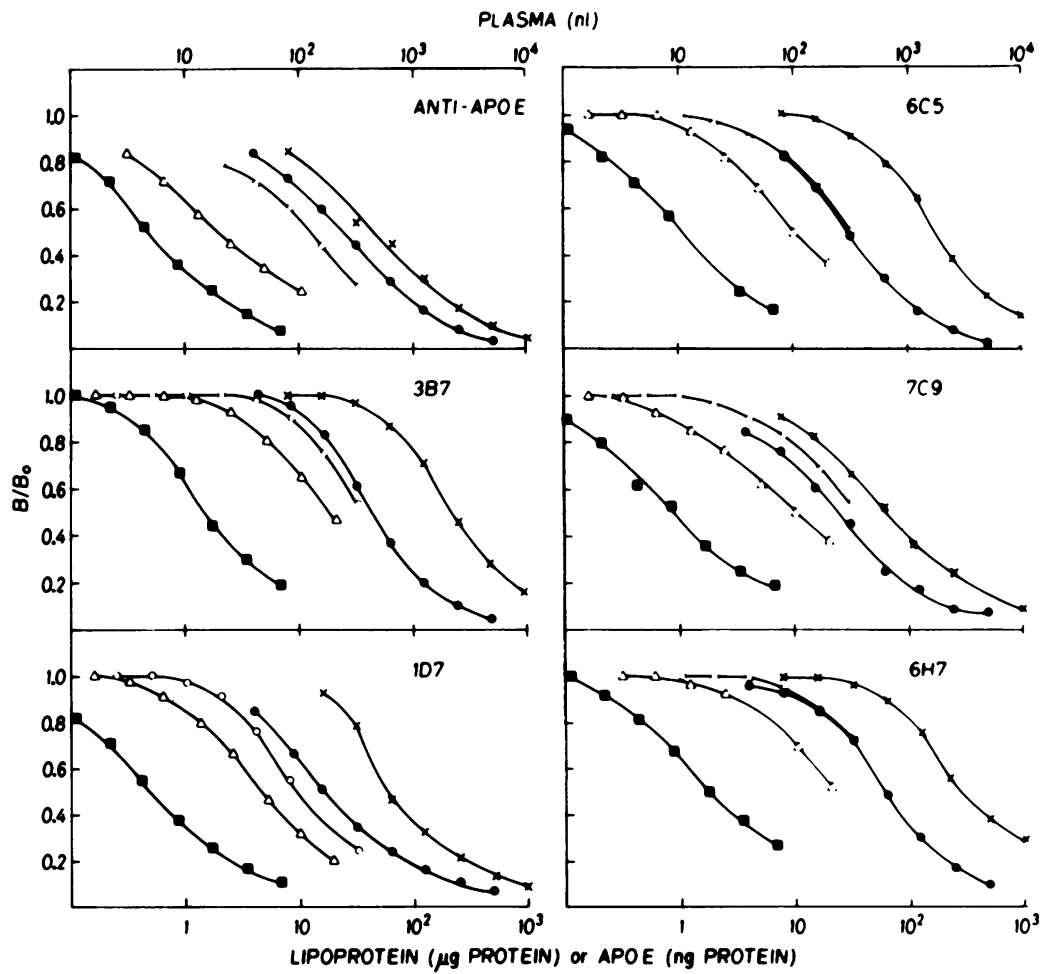

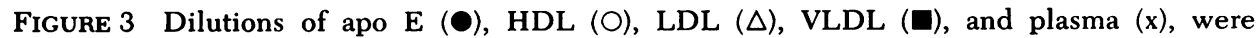
tested for their ability to compete with ${ }^{125}$ I-human apo E. The five monoclonal antibodies or polyclonal anti-apo $\mathrm{E}$ antibodies were used as the antibody component. 
TABLE I

Apo E Concentrations in Plasma as Determined in RIA by Means of Different Antibodies

\begin{tabular}{lccccc}
\hline & \multicolumn{5}{c}{ Apo E } \\
\cline { 2 - 5 } & \multicolumn{5}{c}{ Antibody } \\
\cline { 2 - 6 } & 3B7 & $6 \mathrm{C} 5$ & $6 \mathrm{H} 7$ & $7 \mathrm{C} 9$ & $\begin{array}{c}\text { Polyclonal } \\
\text { anti-apo E }\end{array}$ \\
\hline & & $\mu \mathrm{kg} / \mathrm{ml}$ & \\
Normal $(n=6)$ & $54 \pm 11$ & $58 \pm 11$ & $54 \pm 10$ & $46 \pm 9$ & $69 \pm 23$ \\
Type II $(n=10)$ & $60 \pm 16$ & $54 \pm 17$ & $50 \pm 15$ & $49 \pm 18$ & $63 \pm 17$ \\
Type III $(n=1)$ & 600 & 600 & 520 & 480 & 800 \\
Type III $(n=1)$ & 250 & 260 & 220 & 200 & 360 \\
Type IV $(n=10)$ & $75 \pm 25$ & $58 \pm 39$ & $62 \pm 33$ & $61 \pm 33$ & $78 \pm 33$ \\
\hline
\end{tabular}

tribution of apo E. In normal subjects $34,10,20$, and $36 \%$ were found in the VLDL, LDL, HDL, and $d$ $>1.21$ fractions, respectively, whereas the values were $34,7,12$, and $47 \%$ in type III patients.

The within-assay coefficient of variation was $6 \%$ when 10 replicate plasma samples were included in the assay. This value represents the mean of three experiments. The between-assay coefficient of variation was 9\% when the same plasma sample was measured 15 times in duplicate over a 2-mo period.

The assay for apo $\mathrm{E}$ was validated by a series of parallel determinations of apo E levels by RIA and by densitometric scanning of apo VLDL analyzed by sodium dodecyl sulfate-polyacrylamide gel electrophoresis. Apo VLDL from four hyperlipoproteinemic patients were electrophoresed each at three different protein levels, and a linear standard curve was drawn from a series of purified apo $E$ standards, electrophoresed, stained, and scanned in the same conditions. The correlation between the apo $\mathrm{E}$ levels measured by RIA and by densitometric scanning was 0.999 , whereas the RIA-determined levels were $85 \%$ of those measured by scanning.

Reactivity of monoclonal antibodies with isomorphs of apo E. The isomorphs of apo E, isolated by preparative isoelectrofocusing, were verified by analytical isoelectrofocusing, which showed that the apo $E_{2}$ fraction was slightly contaminated with apo $E_{3}$, and that there was a contamination of the apo $E_{1}$ fraction with apo AI. In the latter case the degree of contamination was estimated by scanning the analytical gels after staining with Coomassie Blue G250 and the apo $\mathrm{E}$ concentration was appropriately corrected for this contamination (20).

The individual isomorphs were tested in the RIA for their ability to compete with ${ }^{125}$ I-apo E (Fig. 4). The antibodies recognize all of the isomorphs. With certain antibodies small differences in reactivities of individual isomorphs were seen as indicated by relative shifts of the competition curves. Although small, these differences were reproducible.
Reactivity of antibodies with chemically modified $V L D L$. In an attempt to demonstrate that the different monoclonal antibodies recognize distinct antigenic determinants on apo $\mathrm{E}$, the antibodies were tested for their ability to recognize apo $\mathrm{E}$ in chemically-modified VLDL. Lysine residues of VLDL were modified by carbamylation or by reductive methylation, and the modified lipoprotein was tested for its ability to compete in the RIA with ${ }^{125}$ I-apo-E. The

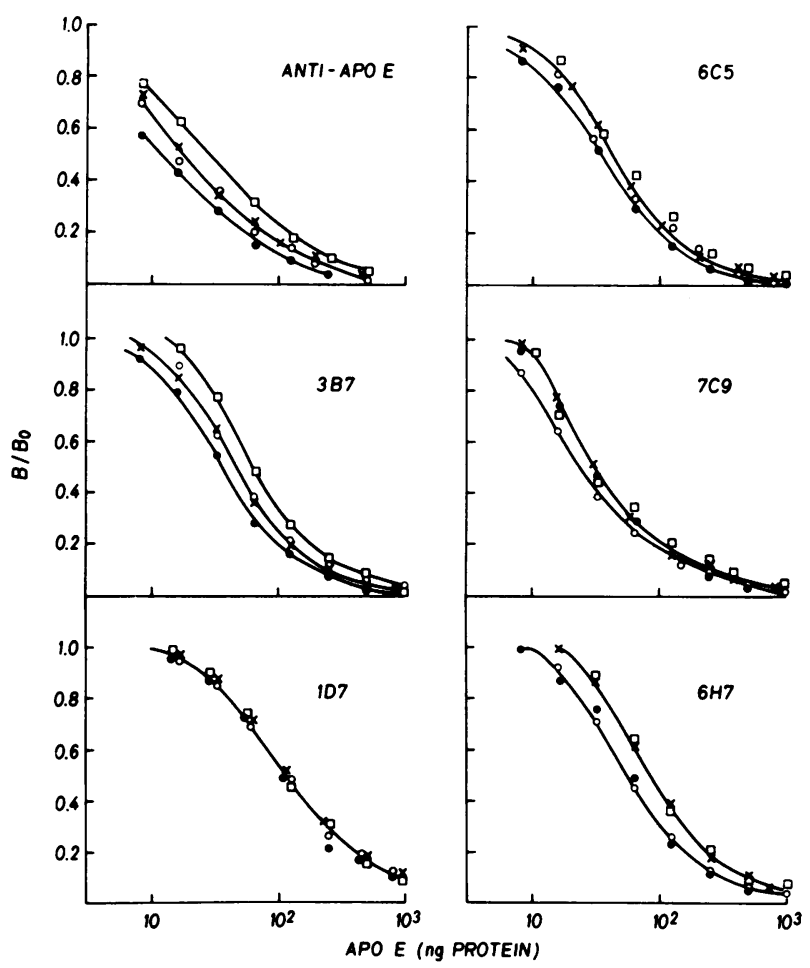

Figure 4 Dilutions of the isomorphs apo $E_{1}(\Theta)$, apo $E_{2}(x)$, apo $E_{3}(O)$, and apo $E_{4}(\square)$ isolated by isoelectrofocusing were tested for their ability to complete with ${ }^{125} \mathrm{I}$-human apo E. The five monoclonal antibodies or polyclonal anti-apo $\mathrm{E}$ were used as the antibody component. 
TABLE II

Measurable Apo E in Chemically Modified VLDL

\begin{tabular}{|c|c|c|c|c|c|c|}
\hline \multirow[b]{4}{*}{ Antibody } & \multicolumn{6}{|c|}{ Percentage of starting reactivity } \\
\hline & \multirow{2}{*}{\multicolumn{2}{|c|}{$\frac{\text { Carbamylated }}{20 \mathrm{~h}}$}} & \multicolumn{4}{|c|}{ Methylated } \\
\hline & & & \multicolumn{2}{|c|}{$30 \mathrm{~min}$} & \multicolumn{2}{|c|}{$60 \mathrm{~min}$} \\
\hline & $\begin{array}{c}\text { Experiment } \\
\text { a }\end{array}$ & $\begin{array}{c}\text { Experiment } \\
\mathrm{b}\end{array}$ & $\begin{array}{c}\text { Experiment } \\
\mathrm{a}\end{array}$ & $\begin{array}{c}\text { Experiment } \\
\text { b }\end{array}$ & $\begin{array}{c}\text { Experiment } \\
\text { a }\end{array}$ & $\begin{array}{c}\text { Experiment } \\
\mathrm{b}\end{array}$ \\
\hline $1 \mathrm{D} 7$ & $42 \pm 2$ & $13 \pm 4$ & $15 \pm 5$ & $8 \pm 4$ & $13 \pm 3$ & $8 \pm 4$ \\
\hline $3 \mathrm{~B} 7$ & $126 \pm 5$ & $166 \pm 50$ & $36 \pm 19$ & $38 \pm 3$ & $13 \pm 4$ & $35 \pm 2$ \\
\hline $6 \mathrm{C5}$ & $133 \pm 5$ & $186 \pm 11$ & $31 \pm 2$ & $37 \pm 4$ & $33 \pm 6$ & $33 \pm 2$ \\
\hline $6 \mathrm{H} 7$ & $155 \pm 8$ & $158 \pm 5$ & $55 \pm 5$ & $32 \pm 2$ & $50 \pm 2$ & $35 \pm 3$ \\
\hline 7C9 & $123 \pm 12$ & $236 \pm 23$ & $40 \pm 4$ & $26 \pm 4$ & $37 \pm 6$ & $26 \pm 4$ \\
\hline Anti-apo $\mathrm{E}$ & $89 \pm 17$ & $74 \pm 16$ & $30 \pm 4$ & $14 \pm 3$ & $25 \pm 4$ & $11 \pm 2$ \\
\hline
\end{tabular}

residual measurable apo $\mathrm{E}$ in modified VLDL expressed as a percentage of the initial concentration in unmodified VLDL is shown in Table II. Carbamylation of VLDL resulted in an increase in measurable apo $\mathrm{E}$ as determined by four of the monoclonal antibodies (3B7, 6C5, 6H7, 7C9). On the other hand, the same treatment caused a large decrease in apo $E$ reactivity with the antibody 1D7. Carbamylation of VLDL resulted in a small decrease in the apo $E$ determined by polyclonal anti-apo $\mathrm{E}$. Reductive methylation of VLDL decreased the apo $E$, as measured by all of the antibodies. The recognition by the antibody 1D7 again appeared to be more susceptible to modification of lysine residues.

When arginine residues of VLDL were modified by treatment with cyclohexanedione, the increase in incubation times from 15 to $120 \mathrm{~min}$ caused a progressive decrease in measurable apo $\mathrm{E}$ content, as determined by all of the antibodies (results not shown).

\section{DISCUSSION}

From a single cell fusion experiment, five stable hybridomas were obtained that secrete antibodies against human apo $\mathrm{E}$. The antibodies show little reactivity against other apoproteins and react with apo $\mathrm{E}$ when it is present in intact lipoproteins. Determination of apo $\mathrm{E}$ concentrations in plasma by a solidphase RIA gave values that are similar to those recently reported by others $(21,22)$. Although there was good correlation between the values obtained with individual antibodies, there were differences in the absolute values measured. This may indicate that when apo $E$ is present in lipoproteins certain antigenic determinants are partially inaccessible to antibody, or that their conformation is slightly altered. There is some precedent for this idea, as, for example, the majority of antigenic determinants on apo AI are hidden or altered in HDL when measured by RIA (23). Nevertheless, methods used to expose determinants of apo AI (delipidation, urea, etc.) had little effect in the present study. Furthermore, the same differences among the antibodies in absolute apo $\mathrm{E}$ determinations were also observed in lipoproteins isolated by ultracentrifugation, including the $d>1.21 \mathrm{~g} / \mathrm{ml}$ infranate, which is relatively poor in lipid. Thus, the apparently decreased recognition by certain monoclonal antibodies of apo $\mathrm{E}$ incorporated in lipoproteins appears to be independent of the lipid/protein ratio and the size of the particle. Nevertheless, even relatively small amounts of lipid, as might be present in the $d$ $>1.21$ infranate, may interfere with the antibodyantigen interaction either by steric hindrance or by slightly altering apo E conformation. Alternatively, certain antibodies may be directed against determinants which had been altered during the purification of apo $\mathrm{E}$ on heparin-Sepharose, and their affinity may thus be higher for these altered forms than for the native determinants. On the other hand, certain antibodies against native determinants may poorly recognize altered determinants of the apo $\mathrm{E}$ standard, and thus overestimate apo $\mathrm{E}$ concentrations.

All of the antibodies recognized all of the isomorphs of apo E. Havel et al. (22) have recently shown immunological identity among the apo $\mathrm{E}$ isomorphs by double immunodiffusion and identical reactivity in the radioimmunoassay. With some of the antibodies, however, we did observe small relative shifts of the competition curves, which could indicate small differences in the relative affinities of the antibodies for the individual isomorphic species.

Differences among the clones in their ability to react with chemically modified proteins were observed. Modification of lysine residues of VLDL by carbamylation caused an increase in reactivity with the monoclonal antibodies $3 \mathrm{~B} 7,6 \mathrm{C} 5$, and $6 \mathrm{H} 7$. In contrast, the antibody 1D7 recognized carbamylated VLDL very poorly. The recognition of apo $E$ in VLDL by $1 D 7$ was also much more susceptible to modification of the VLDL 
by reductive methylation. This would suggest that a lysine residue is present in the antigenic determinant recognized by $1 D 7$ or that the conformation of this determinant is radically altered when lysine residues elsewhere in the molecule are modified. In either case, the specificity of 1D7 can be clearly distinguished from those of the other antibodies.

In conclusion, the five monoclonal antibodies described are specific to apo $E$. Differences in their relative reactivities with apo $E$ in the form of lipoproteins would be consistent with different intramolecular specificities. The specificity of one of the antibodies (1D7) can be distinguished by its reactivity with chemically modified VLDL. Reactivity of individual monoclonal antibodies with chemical or proteolytic digests of apo $\mathrm{E}$ should allow a precise localization of antigenic determinants on the apo $\mathrm{E}$ molecule.

\section{ACKNOWLEDGMENTS}

We are indebted to Dr. J. P. Vaerman and Dr. R. Verdery for valuable discussion, and to Dr. J. Davignon of the Clinical Research Institute of Montreal for providing plasma samples from his patients. We acknowledge the excellent technical assistance of Ms. Louise Blanchette, Ms. Diane Emond, and Ms. Camilla Vézina and the fine secretarial help of Ms. Louise Lalonde.

This study was supported by grants from the Medical Research Council of Canada (.MT-4011), from the Quebec Heart Foundation, and from the Conseil de la Recherche en Santé du Québec.

\section{REFERENCES}

1. Marsh, J. B. 1976. Apoproteins of the lipoproteins in a nonrecirculating perfusate of rat liver.J. Lipid Res. 17: 85-90.

2. Felker, T. E., M. Fainaru, R. L. Hamilton, and R. J. Havel. 1977. Secretion of the arginine-rich and AI apolipoproteins by the isolated perfused rat liver. J. Lipid Res. 18: 465-473.

3. Wu, A.-L., and H. G. Windmueller. 1979. Relative contributions by liver and intestine to individual plasma apolipoproteins in the rat. J. Biol. Chem. 254: 7316-7322.

4. Brown, M. S., and J. L. Goldstein. 1974. Binding and degradation of low density lipoproteins by cultured human fibroblasts: comparison of cells from a normal subject and from a patient with homozygous familial hypercholesterolemia. J. Biol. Chem. 249: 5153-5161.

5. Bersot, T. P., R. W. Mahley, M. S. Brown, and J. L. Goldstein. 1976. Interaction of swine lipoproteins with the low density lipoprotein receptor in human fibroblasts. J. Biol. Chem. 251: 2395-2398.

6. Weisgraber, K. H., T. L. Innerarity, and R. W. Mahley. 1978. Role of the lysine residues of plasma lipoproteins in high affinity binding to cell surface receptors on human fibroblasts. J. Biol. Chem. 253: 9053-9062.

7. Mahley, R. W., T. L. Innerarity, R. E. Pitas, K. H. Weisgraber, J. H. Brown, and E. Gross. 1977. Inhibition of lipoprotein binding to cell surface receptors of fibroblasts following selective modification of arginyl residues in arginine-rich and B apoproteins. J. Biol. Chem. 252: $7279-7287$.

8. Quarfordt, S., J. Hanks, R. S. Jones, and F. Shelburne. 1980. The uptake of high density lipoprotein cholesteryl ester in the perfused rat liver. J. Biol. Chem. 255: $29: 34-2937$.

9. Mahley, R. W., K. H. Weisgraber, T. L. Innerarity, and H. G. Windmueller. 1979. Accelerated clearance of lowdensity and high-density lipoproteins and retarded clearance of $\mathrm{E}$ apoprotein-containing lipoproteins from the plasma of rats after modification of lysine residues. Proc. Natl. Acad. Sci. L. S. A. 76: 1746-1750.

10. Shelburne, F. A., and S. Quarfordt. 1977. The interaction of heparin with an apoprotein of human very low density lipoprotein. J. Clin. Incest. 60: 944-950.

11. Marcel, Y. L., M. Bergseth, and A. C. Nestruck. 1979. Preparative isoelectric focussing of apolipoproteins $\mathrm{C}$ and E from human very low density lipoproteins. Biochim. Biophys. Acta. 573: 175-183.

12. Schulman, M., C. D. Wilde, and G. Kohler. 1978. A better cell line for making hybridomas secreting specific antibodies. Nature (Lond.). 276: 269-270.

13. Tung, A. S., S-T. Su, S. Sato, and A. Nisonoff. 1976. Production of large amounts of antibodies in individual mice. J. Immunol. 116: 676-683.

14. Kennet, A. H., K. A. Denis, A. S. Tung, and N. R. Klinman. 1978. Hybrid plasmacytoma production: fusions with adult spleen cells, monoclonal spleen fragments, neonatal spleen cells, and human spleen cells. Curr. Top. Microbiol. Immunol. 81: 77-91.

15. Littlefield, J. W. 1964. Selection of hybrids from matings of fibroblasts in vitro and their presumed recombinants. Science (Wash. D. C.). 145: 709-710.

16. Chalon M-P., R. W. Milne, and J.-P. Vaerman. 1979. In vitro immunosuppressive effect of serum from orally immunized mice. Eur. J. Immunol. 9: 747-751.

17. Ey, P. L., S. J. Prause, and C. R. Jenkin. 1978. Isolation of pure IgGl, IgG2a and IgG2b immunoglobulins from mouse serum using Protein A-Sepharose. Immunochemistry. 15: 429-436.

18. Bolton, A. E., and W. M. Hunter. 1973. The labelling of proteins to high specific radioactivities by conjugation to a ${ }^{125}$ I-containing acylating agent: application to the radioimmunoassay. Biochem. J. 133: 529-539.

19. McConahey, P. J., and F. J. Dixon. 1966. A method of trace iodination of proteins for immunologic studies. Int. Arch. Allergy Appl. Immunol. 29: 185-193.

20. Warnick, G. R., C. Mayfield, J. J. Albers, and W. R. Hazzard. 1979. Gel isoelectric focusing method for specific diagnosis of familial hyperlipoproteinemia type 3. Clin. Chem. 25: 279-284.

21. Blum, C. G., L. Aron, and R. Sciacca. 1980. Radioimmunoassay studies of human apolipoprotein E. J. Clin. Invest. 66: 1240-1250.

22. Havel, R. J., L. Kotite, J. L. Vigne, J. P. Kane, P. Tun, N. Phillips, and G. C. Chen. 1980. Radioimmunoassay of human arginine-rich apolipoprotein, apoprotein $\mathrm{E}$. J. Clin. Invest. 66: 1.351-1362.

23. Schonfeld, G., and B. Pfleger. 1974. The structure of human high density lipoprotein and the levels of apoprotein $\mathrm{A}-1$ in plasma as determined by radioimmunoassay. J. Clin. Invest. 54: 236-246. 